\title{
LIABILITY UNDER RULE 10b-5 FOR NEGLIGENTLY MISLEADING CORPORATE RELEASES: A PROPOSAL FOR THE APPORTIONMENT OF LOSSES
}

The determination of liability and the assessment of damages for materially misleading statements made by corporations in connection with the sale of their securities has long been troublesome. ${ }^{1}$ By definition, a materially misleading statement has an impact on the decisions made by investors with regard to securities issued by the corporation in question. ${ }^{2} \mathrm{~A}$ misleading statement made to a single investor in a face-to-face transaction may involve only a small loss or gain. However, when a statement in a nationally published press release is materially misleading, all investors may be exposed to it and may make investment decisions relying on it. Such a situation can involve thousands of investors and millions of dollars in damages.

As a matter of equity, there can be little doubt that a corporation should bear the losses caused by its fraudulent or knowingly misleading public statements. On the other hand, imposition of liability for a statement that is misleading only because of negligence in its preparation ${ }^{3}$ is a more difficult issue;

${ }^{1}$ Materially misleading statements or omissions in connection with the purchase or sale of securities are proscribed by $\S 10(b)$ of the Securities Exchange Act of 1934,15 U.S.C. $\$ 78 \mathrm{j}(\mathrm{b})(1970)$, which makes it unlawful to use or employ, in connection with the purchase or sale of any security registered on a national securities exchange or any security not so registered, any manipulative or deceptive device or contrivance in contravention of such rules and regulations as the Commission may prescribe as necessary or appropriate in the public interest or for the protection of investors;

and by rule $10 \mathrm{~b}-5,17$ C.F.R. $\S 240.10 \mathrm{~b}-5$ (1973), promulgated pursuant thereto, providing:

It shall be unlawful for any person, directly or indirectly, by the use of any means or instrumentality of interstate commerce, or of the mails, or of any facility of any national securities exchange,

(a) to employ any device, scheme, or artifice to defraud,

(b) to make any untrue statement of a material fact or to omit to state a material fact necessary in order to make the statements made, in the light of the circumstances under which they were made, not misleading, or

(c) to engage in any act, practice, or course of business which operates or would operate as a fraud or deceit upon any person, in connection with

the purchase or sale of any security.
2 "The basic test of 'materiality'. . is whether 'a reasonable man would attach importance [to the fact misrepresented] in determining his choice of action in the transaction in question.' " List v. Fashion Park, Inc., 340 F.2d 457, 462 (2d Cir.), cert. denied, 382 U.S. 811 (1965) (quoting RESTATEMENT OF TORTS \$ 538(2) (a) (1938)).

${ }^{3}$ Whether fraudulently or negligently prepared, statements not in connection with the sale or purchase of securities fall outside the scope of the civil liability provisions of the federal securities laws. Section 11 of the Securities Act of 1933, 15 U.S.C. $\S 77 \mathrm{k}$ (1970), dealing with false and incomplete registration statements, and $\S 12$ of the Securities Act of 1933 , id. $\S 771$, dealing with prospectuses and other communications, 
it may appear undesirable to impose heavy damages for such a relatively slight degree of fault. This Comment will discuss some of the problems inherent in cases arising under rule $10 \mathrm{~b}-5^{4}$ which involve negligently misleading public statements and press releases. It will suggest that losses in such cases are best spread among all the parties involved. These parties include the corporation and its preexisting shareholders, as well as those investors who bought or sold relying on the misleading corporate statement. It will be suggested that, in cases of negligence, the resolution of conflicting policies requires a measure of damages less rigorous than an "all-or-nothing" liability. ${ }^{5}$

\section{THE Texas GulfSulphur CASE}

The extensive litigation arising over a press release that was issued by the Texas Gulf Sulphur Company (TGS) ${ }^{6}$ on April 12,

apply only to those plaintiffs who purchased securities from the defendant corporation. Section 10(b) of the Securities Exchange Act of 1934, id. $\S 78 \mathrm{j}(\mathrm{b})$, applies to deceptive devices used in connection with the purchase or sale of securities. Section 18(a) of the Securities Exchange Act of 1934 , id. $\$ 78 \mathrm{r}(\mathrm{a})$, applies only to misleading statements and misrepresentations contained in documents filed under the Exchange Act.

${ }^{4}$ 17 C.F.R. $\$ 240.10 b-5$ (1973).

${ }^{5}$ We thus follow the lead of the Supreme Court in J.I. Case Co. v. Borak, 377 U.S. 426, 433-35 (1964), which held that the federal courts are not bound by rigid rules in shaping their judgments under the securities laws to the equities of individual cases:

[I] $t$ is the duty of the courts to be alert to provide such remedies as are necessary to make effective the congressional purpose.... It is for federal courts 'to adjust their remedies so as to grant the necessary relief' when federally secured rights are invaded.

Id. at 433. See notes 44-57 infra \& accompanying text.

${ }^{6}$ The Texas Gulf Sulphur litigation, further described in notes 7-28 infra \& accompanying text, includes 4 different actions and 24 reported opinions. In chronological order, the opinions are as follows, with the number on the left serving to indicate to which separate action the opinion belongs:

SEC v. TGS

258 F. Supp. 262 (S.D.N.Y. 1966)

TGS v. Ritter

371 F.2d 14.5 (10th Cir. 1967)
SEC v. TGS

Cannon v. TGS

Coates v. SEC

Astor v. TGS

Reynolds v. TGS

Reynolds v. TGS

SEC v. TGS
401 F.2d 833 (2d Cir. 1968)

47 F.R.D. 60 (S.D.N.Y. 1969)

394 U.S. 976 (1969)

306 F. Supp. 1333 (S.D.N.Y. 1969)

309 F. Supp. 548 (D. Utah 1970)

309 F. Supp. 566 (D. Utah 1970)

312 F. Supp. 77 (S.D.N.Y. 1970) findings of fact and law denial of writs of mandamus and prohibition

rev'g

establish a class action cert. denied motions for summary judgment held for plaintiffs denial of class action violations; remedies 
$1964^{7}$ presents the obvious departure point for an analysis of judicial interpretation of rule $10 \mathrm{~b}-5$ in the context of a misleading corporate disclosure. ${ }^{8}$ Although the basic fácts of that case are well known, a brief restatement will be helpful. ${ }^{9}$ TGS had been exploring for minerals in eastern Canada for several years when it discovered a potentially rich ore site in late 1963. Initial drilling indicated a great likelihood of an inordinately rich copper strike. Two major New York Newspapers quickly reported rumors of the strike. Officers of TGS countered almost immediately by issuing the now-famous press release of April 12, 1964 , denying the accuracy of the rumors, reporting that most of the findings onsite were valueless, and generally espousing a pessimistic view of the explorations. In fact, TGS officers were fairly certain that a rich ore site had been found. Four days after the initial press release, TGS issued a detailed statement announcing a strike of at least 25 million tons of ore. In the

\begin{tabular}{|c|c|c|c|}
\hline 4 & Fink v. Coates & 323 F. Supp. 988 (S.D.N.Y. 1971) & $\begin{array}{l}\text { denial of collateral } \\
\text { estoppel } \\
\text { from } 309 \text { F. Supp. } \\
548\end{array}$ \\
\hline 3 & Cannon v. TGS & 323 F. Supp. 990 (S.D.N.Y. 1971) & $\begin{array}{l}\text { denial of collateral } \\
\text { estoppel } \\
\text { from Reynolds and } \\
S E C \text { v. TGS }\end{array}$ \\
\hline 2 & Mitchell v. TGS & 446 F.2d 90 (10th Cir. 1971) & $\begin{array}{l}\text { aff'g; modifying } \\
\text { damage formula }\end{array}$ \\
\hline 3 & Cannon v. TGS & 53 F.R.D. 216 (S.D.N.Y. 1971) & motions denied \\
\hline 1 & SEC v. TGS & 446 F.2d 1301 (2d Cir. 1971) & appeal of remedies \\
\hline 3 & Cannon v. TGS & 53 F.R.D. 220 (S.D.N.Y. 1971) & $\begin{array}{l}\text { motion to revoke } \\
\text { class status denied }\end{array}$ \\
\hline 1 & SEC v. TGS & 331 F. Supp. 671 (S.D.N.Y. 1971) & $\begin{array}{l}\text { order as to defen- } \\
\text { dant Kline }\end{array}$ \\
\hline 3 & Cannon v. TGS & 55 F.R.D. 306 (S.D.N.Y. 1971) & $\begin{array}{l}\text { denial of certain } \\
\text { classes }\end{array}$ \\
\hline 2 & TGS v. Mitchell & 404 U.S. $1004(1971)$ & cert. denied \\
\hline 1 & TGS v. SEC & 404 U.S. $1005(1971)$ & cert. denied \\
\hline 1 & TGS v. SEC & 404 U.S. $1064(1972)$ & rehearing denied \\
\hline 2 & TGS v. Mitchell & 404 U.S. $1064(1972)$ & rehearing denied \\
\hline 2 & Reynolds v. TGS & 40.5 U.S. $918(1972)$ & cert. denied \\
\hline 3 & $\begin{array}{l}\text { Cannon } v \text {. TGS } \\
\text { In re TGS } \\
\text { Litigation }\end{array}$ & $\begin{array}{l}55 \text { F.R.D. } 308 \text { (S.D.N.Y. 1972) } \\
344 \text { F. Supp. } 1398 \text { (J.P.M.L. 1972) }\end{array}$ & $\begin{array}{l}\text { settlement } \\
\text { transfer to S.D.N.Y. }\end{array}$ \\
\hline
\end{tabular}

Cannon class $=$ all persons who sold TGS stock between 4-12-64 and 10:55 a.m. on 4-16-64, at $\$ 33$ or less, in reliance on 4-12-64 press release.

${ }^{7}$ SEC v. Texas Gulf Sulphur Co., 258 F. Supp. 262, 292-93 (S.D.N.Y. 1966).

${ }^{8}$ The litigation was complicated by the presence of insider trading, but this issue is analytically distinct and was treated separately from the question of the misleading press release.

${ }^{9}$ For exhaustive renditions of these facts, see Mitchell v. Texas Gulf Sulphur Co., 446 F.2d 90, 93-95 (10th Cir. 1971); SEC v. Texas Gulf Sulphur Co., 401 F.2d 833, 843-47 (2d Cir. 1968); Reynolds v. Texas Gulf Sulphur Co., 309 F. Supp. 548, 551-56 (D. Utah 1970); SEC v. Texas Gulf Sulphur Co., 258 F. Supp. 262, 268-75, 292-94 (S.D.N.Y. 1966). 
following month, the price of TGS stock nearly doubled..$^{10}$ Three major lawsuits against TGS followed.

The first was an action by the SEC, seeking a permanent injunction barring the company from issuing further misleading press releases. ${ }^{11}$ Reversing the trial court's finding that the press release, while gloomy and incomplete, was neither misleading nor deceptive, ${ }^{12}$ the Second Circuit en banc adopted a negligence standard for the determination whether injunctive relief should issue. The case was remanded for findings on whether the April 12 press release would have misled the reasonable investor and whether TGS had used due diligence in issuing it. $^{13}$ Although the court expressly did not decide whether mere negligence would subject TGS to liability in a private damage suit, ${ }^{14}$ five of the nine judges went beyond the issues before them to express their opposition to such a standard. ${ }^{15}$

The second major action against TGS was instituted by six plaintiffs, seeking damages, in the District of Utah. ${ }^{16}$ The trial court found the release "misleading, intentionally deceptive, inaccurate, and knowingly deficient in material facts." appeal the Tenth Circuit held that this result, while correct, overstated the plaintiffs' burden. The defendant corporation had

${ }^{10} 309$ F. Supp. at 564 n.23.

${ }^{11}$ SEC v. Texas Gulf Sulphur Co., 258 F. Supp. 262 (S.D.N.Y. 1966).

${ }^{12} I d$. at 296.

${ }^{13} 401$ F.2d at 863 . After describing the requirement that a reasonable investor must have been misled by the release before an injunction would issue, the court stated:

We hold only that, in an action for injunctive relief, the district court has the discretionary power under Rule 10b-5 and Section 10(b) [of the Securities Exchange Act of 1934,15 U.S.C. $\$ 78 \mathrm{j}(\mathrm{b})(1970)]$ to issue an injunction, if the misleading statement resulted from a lack of due diligence on the part of TGS.

Id.

${ }^{14}$ See id. The Seventh, Eighth, Ninth and Tenth Circuits have discarded the scienter requirement-adopting a negligence standard-in private damage actions involving face-to-face transactions. Myzel v. Fields, 386 F.2d 718, 734-35 (8th Cir. 1967), cert. denied, 390 U.S. 951 (1968); Stevens v. Vowell, 343 F.2d 374, 379 (10th Cir. 1965); Royal Air Properties, Inc. v. Smith, 312 F.2d 210, 212 (9th Cir. 1962); Ellis v. Carter, 291 F.2d 270, 274 (9th Cir. 1961); Kohler v. Kohler Co., 208 F. Supp. 808, 823 (E.D. Wis. 1962) (dictum), aff'd, 319 F.2d 634, 637 (7th Cir. 1963). A district court in the Fourth Circuit has indicated that negligence is sufficient to establish liability under rule $10 \mathrm{~b}-5$, and that scienter is unnecessary. Batchelor v. Legg \& Co., 52 F.R.D. 545, 549 (D. Md. 1971).

One Third Circuit judge has opined that all of the language in the above cases dispensing with the scienter requirement is dictum. Kohn v. American Metal Climax, Inc., 458 F.2d 255, 286 (3d Cir.) (Adams, J., concurring \& dissenting), cert. denied, 409 U.S. 874 (1972).

${ }^{15} 401$ F.2d at 866-67 (Friendly, J.), 869 (Kaufman \& Anderson, JJ.), 870-89 (Moore, J., \& Lumbard, C.J., dissenting) (Moore and Lumbard would not even grant an injunction based on a negligently prepared release).

${ }^{16}$ Reynolds v. Texas Gulf Sulphur Co., 309 F. Supp. 548 (D. Utah 1970). TGS tried unsuccessfully to have this action transferred to the Southern District of New York. Texas Gulf Sulphur Co. v. Ritter, 371 F.2d 145 (10th Cir. 1967).

${ }^{17} 309$ F. Supp. at 563-64. 
"the burden of proving that [it] did not know, and in the exercise of reasonable care could not have known" of the inaccuracies in the release-a negligence standard. ${ }^{18}$ The measure of damages adopted was "the amount it would have taken [a reasonable investor] to invest in the TGS market within a reasonable period of time after he became informed of the April 16 release." 19 The total recovery was relatively small, however; this action involved only 2,020 shares of TGS stock. ${ }^{20}$

The third major action against TGS was a class action representing a potential 364,000 shares of TGS stock. ${ }^{21}$ The trial court, refusing to apply collateral estoppel with respect to either the SEC action or the Utah litigation, ${ }^{22}$ read the dictum of the Second Circuit" to mean that "plaintiffs must show more than that the April 12 press release was negligently prepared. They must show some degree of scienter." 24 The class action and all other private actions brought against TGS in the Southern District of New York were finally settled early in $1972 .^{25}$

In only one of the three major actions did the court cast the test of liability for private damages in terms of negligence. ${ }^{26}$ The Second Circuit impliedly rejected the negligence standard in

${ }^{18} 446$ F.2d at 102 (quoting Gilbert v. Nixon, 429 F.2d 348, 357 (10th Cir. 1970)).

${ }^{19} \mathrm{Id}$. at 105 . Concluding that a reasonable investor would have learned of the April 16 release by April 20, and that 9 trading days thereafter (through May 1) gave the investor a reasonable time to decide whether or not to reinvest, the court awarded damages equal to the difference between plaintiffs' sale price and $\$ 59$, the highest price reached by TGS stock between April 20 and May 1. The trial court had used a different measure. It awarded the difference between the sale price and $\$ 50.75$, the average of the highest daily prices reached during the reasonable time of 20 trading days after the April 16 release. 309 F. Supp. at 563-65.

20309 F. Supp. at 556.

${ }^{21}$ Cannon v. Texas Gulf Sulphur Co., 47 F.R.D. 60, 63 (S.D.N.Y. 1969). The class was composed of those who sold TGS stock between April 12 and 10:55 a.m. on April 16, inclusive, in reliance on the April 12 release. Id. at 61; Cannon v. Texas Gulf Sulphur Co., 323 F. Supp. 990, 992 (S.D.N.Y. 1971).

${ }^{22}$ Cannon v. Texas Gulf Sulphur Co., 323 F. Supp. 990, 992-94 (S.D.N.Y. 1971);

Fink v. Coates, 323 F. Supp. 988, 989-90 (S.D.N.Y. 1971).

${ }^{23}$ Text accompanying note 15 supra.

${ }^{24}$ Astor v. Texas Gulf Sulphur Co., 306 F. Supp. 1333, 1344 (S.D.N.Y. 1969).

${ }^{25}$ Cannon v. Texas Gulf Sulphur Co., 55 F.R.D. 308 (S.D.N.Y. 1972).

Use of the Tenth Circuit's measure of damages would have resulted in a total liability to the class of $\$ 10,239,320$, or $\$ 28.13$ per share representing the difference between the weighted average selling price of TGS stock during the April 12-16 period and the cover price. Memorandum of Law in General Counsel in the Above Entitled Consolidated Action and of Counsel for the Class in Support of Settlement, at 22. The $\$ 2,700,000$ settlement provided $\$ 2,200,000$ to the class and to all other plaintiffs who claimed losses suffered in reliance on the April 12 press release; the remaining $\$ 500,000$ went to those plaintiffs who claimed damages based on the sale of TGS stock prior to public disclosure of TGS's mineral exploration. 55 F.R.D. at 310-11. Problems of proof would have been virtually insurmountable for these plaintiffs had there been no settlement. Id . at 317 . The District of Utah trial court had rejected a similar claim. $309 \mathrm{~F}$. Supp. at 558-59.

${ }^{26}$ Text accompanying note 18 supra. 
Texas Gulf Sulphur, ${ }^{27}$ and has explicitly done so in several subsequent cases. ${ }^{28}$ The issue is a complex one, involving a delicate balance, and requires closer examination.

\section{LIABILITY FOR NEGLIGENT MISREPRESENTATION-A MATTER OF POLICY}

A number of courts have abandoned the scienter requirement in cases involving face-to-face transactions, holding negligent as well as fraudulent behavior within the ambit of rule $10 \mathrm{~b}-5 .{ }^{29}$ Clearly the extension of this development to include market transactions would involve no further interpretive strain upon the statutory provisions. ${ }^{30}$ Thus the question whether a plaintiff should recover damages for negligent misrepresentation is similar to the threshold question whether a civil damage remedy ought to be implied under the rule at all; the answer to both rests on whether such a development advances the underlying purposes of the securities laws. ${ }^{31}$ The overriding policy considerations behind the federal securities laws were stated by the Second Circuit in its Texas Gulf Sulphur opinion:

The dominant congressional purposes underlying the Securities Exchange Act of 1934 were to promote free and open public securities markets and to protect the investing public from suffering inequities in trading, including, specifically, inequities that follow from trading that has been stimulated by the publication of false or misleading corporate information releases. ${ }^{32}$

In light of these policies, blanket extension of liability for the full measure of losses to cases involving negligently prepared, misleading corporate press releases produces some confusing and conflicting analytical results. ${ }^{33}$

\footnotetext{
${ }^{27}$ Text accompanying note 15 supra.

${ }^{28}$ E.g., Lanza v. Drexel \& Co., 479 F.2d 1277, 1305-06 (1973); Cohen v. Franchard Corp., 478 F.2d 115, 123 (1973).

${ }^{29}$ Seenote 14 supra.

${ }^{30}$ Seenote 1 supra \& accompanying text.

${ }^{31}$ Cf. J.I. Case Co. v. Borak, 377 U.S. 426 (1964).

32401 F.2d at 858. See U.S. SECURITIES \& EXCHANGE COMM'N, A 25 YEAR SUMmary OF THE A CTIVITIES OF THE SECURITIES AND EXCHANGE COMMISSION Xiii (1949).

${ }^{33}$ Similar dilemmas have been encountered at common law. When the plaintiffs damages are disproportionate to the defendant's fault, judicial balancing of the equities has proved a devilish problem. See, e.g., Levitin, Accountants'Scope of Liability For Defective Financial Reports, 15 Hastings L.J. 436, 445 (1964), Seavey, Mr. Fustice Cardozo And The Law of T orts, 52 HARV. L. REv. 372,400 (1939). For example, in Jaillet v. Cashman, 235 N.Y. 511, 139 N.E. 714 (1923), the New York Court of Appeals refused to hold the defendant liable for losses caused by an erroneous investment report that was corrected 45 minutes after it was released. It is likely that the losses were very large, and damages would have been out of proportion to the fault. Similarly, in the well-known case of
} 
Several distinct features of actions premised upon negligently prepared corporate press releases must be considered. First, in the absence of insider trading, there is no profit to be disgorged. Courts cannot look to unjust enrichment of the defendant as a justification for liability, nor is there any readily available pool of funds to compensate victims. Second, the losses caused by a publicly disseminated misleading release usually far exceed the ability of the responsible officers to pay. As a result the corporation must be relied upon to compensate the victims, and in the final analysis the corporation is simply an aggregation of shareholders. Although theoretically "responsible" for corporate actions in the sense that their equity is subject to the claims of persons damaged by the corporation, as a practical matter shareholders in all but the most closely held firms are divorced from operations, and are generally as ignorant of the true facts as the plaintiffs in a rule $10 \mathrm{~b}-5$ action.

Third, to the extent that any damages assessed against the corporation are not borne by its shareholders through a decline in the value of their stock, they will most probably be passed on to innocent consumers of the corporation's products. Of course, the extent to which a corporation can recoup by raising prices in response to a damage assessment depends in large part on industry structure and market characteristics. But, to some extent at least, a corporation will be penalized for the protection of the investing public at the expense of the larger consuming public. It is not at all clear that this is a desirable result.

Ultramares Corp. v. Touche, 255 N.Y. 170, 174 N.E. 441 (1931), an accountant was found not liable for damages suffered by the plaintiff in reliance on a negligently prepared financial statement. Speaking for a unanimous court, Judge Cardozo explained, "If liability for negligence exists, a thoughtless slip or blunder . . . may expose accountants to a liability in an indeterminate amount for an indeterminate time to an indeterminate class." Id. at 179,174 N.E. at 449 . On the other hand, the same court was willing to impose liability in a similar factual setting when the damages were small. Glanzer v. Shepard, 233 N.Y. 236; 135 N.E. 275 (1922).

Few courts have rejected the social utilitarianism implicit in Ultramares, and then only when the defendant knew, or should have known, that the plaintiff was relying on his report. See Rhode Island Hospital Trust Nat'l Bank v. Swartz, Bresenoff, Yavner \& Jacobs, 455 F.2d 847, 851 (4th Cir. 1972); Rusch Factors, Inc. v. Levin, 284 F. Supp. 85 (D.R.I. 1968); Ryan v. Kanne, 170 N.W.2d 395, 403 (Iowa 1969); Shatterproof Glass Corp. y. James, 466 S.W.2d 873, 880 (Tex. Civ. App. 1971); Hedley Byrne \& Co. v. Heller \& Partners, Ltd., 3 W.L.R. 101 (H.L. 1963). These courts have generally done so on the rationale that the imposition of liability for reasonably foreseeable (or foreseen) losses would heighten cautionary techniques and would result in a more equitable distribution of losses. See, e.g., Rusch Factors, Inc. v. Levin, supra, at 91.

This rationale-quality control and risk bearing-is at the core of the problem whether to impose liability on corporations for materially misleading press releases. The weight of authority would support nonimposition of liability where the damages are large and corporate resources are limited; but more recent cases endorse the principle that there should be liability even if the damages are large and the fault is small. Proper balancing of these 2 principles in the context of misleading corporate press releases requires a deeper analysis of conflicting policy goals. 
The deterrent policies of the securities laws demand the prevention of negligent misrepresentation as well as fraudulent misrepresentation, for, as noted by the Second Circuit, "the investing public may be injured as much by one's misleading statement containing inaccuracies caused by negligence as by a misleading statement published intentionally to further a wrongful purpose." 34 Fraud is perhaps more easily deterred by civil liability than is negligence, but it cannot be doubted that the fear of civil liability for careless mistakes would reduce the likelihood of mistakes. Despite the ability of a corporation to pass on its damages to consumers through cost increases noted above, the deterrent effect of liability for negligently prepared releases would likely be significant.

Highly respected jurists have argued, however, that civil liability for negligent misrepresentation under rule $10 \mathrm{~b}-5$ would be counterproductive of the goals and policies of the securities laws, specifically full disclosure of material information. Judge Friendly noted:

If the only choices open to a corporation are either to remain silent and let false rumors do their work, or to make a communication, not legally required, at the risk of a slip of the pen or failure properly to amass or weigh the facts-all judged in the brilliant gleam of hindsight-will lead to large judgments, payable in the last analysis by innocent investors, for the benefit of speculators and their lawyers, most corporations would opt for the former. ${ }^{35}$

Assuming that a corporation does not have a duty to correct false rumors ${ }^{36}$ the conclusion that the risk of liability for a negligently insufficient correction would constrict the flow of information to the public is not as inevitable as Judge Friendly indicates. The risk of encouraging limitation of the flow of information is confined to instances in which there is no insider trading; an insider has an obligation to disclose material information when he trades in his corporation's securities. If the securities laws are at all effective it must be assumed that in situations in which insiders are trading, material information has been disclosed to the investing public.

Additionally, business rather than legal considerations are likely to predominate in the decision whether to release information. ${ }^{37}$ Disclosure of unfavorable information to scotch a

${ }^{34} 401$ F.2d at 860 .

${ }^{35}$ SEC v. Texas Gulf Sulphur Co., 401 F.2d 833, 867 (2d Cir. 1968) (Friendly, J., concurring) (emphasis added).

${ }^{36}$ Seenotes 40-41 infra \& accompanying text.

${ }^{37}$ The facts of the TGS litigation provide an excellent example of the dominance of business considerations. See notes 6-28 supra \& accompanying text. 
beneficial rumor can scarcely be expected in any event. A corporation which may need to increase its capitalization cannot afford to permit a collapse in the market for its securities due to an incorrect and uncorrected adverse rumor. Therefore, a corporate officer apprised of material beneficial information would usually not be deterred from releasing that information by the risk of liability due to negligence in the preparation of the release. The effect of finding liability for negligence would be limited to encouraging care in the release of information which, for business reasons, the corporation had already decided to release.

If this assessment is incorrect, however, or if there exists neutral information the release of which may depend heavily upon the legal risks involved, ${ }^{38}$ the conclusion that negligence should not give rise to civil liability remains unsatisfactory. The securities laws are concerned with more than the mere quantum of information released. Of equal or greater importance is the accuracy of that information. The securities laws are designed to encourage full and accurate disclosure. Toleration of misleading statements to encourage greater disclosure is far more destructive of these purposes than insistence upon accurate information at the risk of discouraging the release of information.

If there is danger that liability for negligence may deter the correction of false rumors in instances in which correction is not "legally required," the solution which best comports with the policy favoring full and accurate information is to enforce strict duties of correction and disclosure, not to shield the corporation from responsibility for its negligent errors. Such duties of correction and disclosure do exist; ${ }^{40}$ the Tenth Circuit in Mitchell

${ }^{38} \mathrm{By}$ definition it is extremely unlikely that material information will ever be neutral. See note 2 supra.

${ }^{39}$ SEC v. Texas Gulf Sulphur Co., 401 F.2d 833, 867 (2d Cir. 1968) (Friendly, J., concurring).

${ }^{40}$ In addition to the periodic reports required under $\S 13$ of the Exchange Act, 15 U.S.C. $\$ 78 \mathrm{~m}(1970)$, the SEC and the exchanges require prompt disclosure of all material developments. The SEC's policy is stated as follows:

Notwithstanding the fact that a company complies with ... reporting requirements, it still has an obligation to make full and prompt announcements of material facts regarding the company's financial condition ....

Not only must material facts affecting the company's operations be reported; they must also be reported promptly. Corporate releases which disclose . . . favorable developments but do not even suggest existing adverse corporate developments do not serve the public needs and may violate the antifraud provisions of the Securities Exchange Act of 1934 .

SEC Exchange Act Release No. 8995, [1970-71 Transfer Binder] CCH FED. SEC. L. REP. II 77,915 (Oct. 15, 1970).

The New York Stock Exchange has a similar policy: "A corporation . . . is expected to release quickly to the public any news or information which might reasonably be expected to materially affect the market for securities." NYSE Company Manual A-18. 
rejected the argument that liability for negligence would deter the release of information, noting that "the duty to disclose facts when they become material has not been altered by this decision."41

Admittedly, however, fostering investor protection through civil liability for the full measure of losses caused by negligently prepared press releases produces some serious difficulties. Liability injures a significant segment of the class that the securities laws were designed to protect. Judge Friendly, quoting Milton Cohen, rested heavily on this point in his I exas Gulf Sulphur opinion: "[A] ny remedy imposed against the issuer itself is indirectly imposed on all holders of the common stock, usually the most important segment of the total category of investors intended to be protected." "42 Although the corporation's common shareholders are the most important class of investors to be protected, the body of common shareholders are certainly no more worthy of protection than those who either bought or sold common stock in reliance upon the misleading corporate release. Protectio of both groups counsels neither a total denial nor a total approval of liability, but a balancing of the interests of all parties and and an apportionment of the losses caused by the misleading release among nonrelying shareholders and injured investors. ${ }^{43}$

The assessment of massive damages against the corporation also works a twofold harm upon the consumer. As already noted, consumers may be forced to bear significant cost increases due to the impact of the damage award upon the corporation. There is, perhaps, an additional risk that the crushing burden of liability for a "thoughtless slip or blunder" will occasionally drive the corporation out of business, depriving society of the social and economic benefits of corporate growth.

Resolution of these conflicting policies is difficult, but the denial of liability and the concomitant absence of compensation and deterrence is totally unsatisfactory. To permit the size of the damage award and its adverse consequences to the defendant to dictate the standard of culpability is theoretically distasteful. It is preferable to attempt to deter all misrepresentation, and to permit the degree of culpability to modify the extent of liability. It is, therefore, suggested that liability be found in all cases

The American Stock Exchange explains its policy as follows: "A listed company is required to make immediate public disclosure of all material information concerning its affairs, except in exceptional circumstances." ASE Company Guide 101.

41446 F.2d at 100 .

${ }^{42} 401$ F.2d at 866-67 (quoting Cohen, Truth in Securities Revisited, 79 HARV. L. REv. $1340,1370(1967))$.

${ }^{43}$ Seenotes 47-57 infra \& accompanying text. 
involving negligently prepared, misleading corporate press releases, and that the competing policies be accommodated in the assessment of damages. ${ }^{44}$

\section{TWO APPROACHES TO LIMITING LIABILITY}

\section{A. A Percentage-of-Earnings Approach}

One way to avoid crippling the corporate defendant while retaining the principles of deterrence and compensation in the case of a negligently misleading release would be to tie the payment of the award to corporate earnings. This can be done in either of two ways. First, the damage award might be expressed as a percentage of corporate earnings over a period of time extending forward from the date of judgment. Second, the award could be fixed in amount, but paid out over time out of earnings. Under either method, the greater ease of payment would reflect the corporation's reduced degree of fault; the corporation could continue as a going concern; and plaintiffs would receive significant compensation for their losses.

The former approach of tying the size of the damage award to earnings creates some potential for abuse; it would encourage a corporation to hide its earnings or defer them to a later period, if possible. A corporation that tried to juggle its books could, however, expose itself, its officers and employees to further civil or criminal liability for fraud; and plaintiffs benefiting from the award could be expected to perform a watchdog role. In aid of its judgment a court also could order that the plaintiffs be permitted reasonable access to the corporation's books. In any event, business considerations would be a counterinfluence opposing understatement of earnings. ${ }^{45}$

The potential for abuse is eliminated under the latter percentage-of-earnings approach, in which earnings affect not the size of the award, but only the length of time over which it is paid. The only effect of deferral or concealment of earnings would be to permit "borrowing" of funds interest-free from the plaintiffs. The incentive to do so would be eliminated by

${ }^{44}$ For the purpose of discussion this Comment assumes that courts will not feel strictly bound by traditional methods of computing damages. While the approaches outlined here are novel, they should be available to a federal court fashioning a federal remedy. See note 5 supra. Other issues relevant to the propriety of using such approaches are discussed at notes 58-75 infra \& accompanying text.

${ }_{45}$ The necessity of maintaining a strong financial image among investors would severely restrict the advantages of deliberately deferring or misstating profits. The securities of a corporation carrying a substantial damage judgment as a drain on earnings will not be highly marketable; management would be ill-advised to understate earnings and risk destroying this already-weakened market. 
allowing interest to accrue on the unpaid portion of the award. ${ }^{46}$ This approach also has the advantage of allowing damages to be fixed in amount at the time of judgment. It is probably the better of the two percentage-of earnings approaches, though both adequately deal with the danger of burdening the corporation with destructive damages.

\section{B. An Adjusted Pro Rata Loss Theory of Damages}

The observation that the corporation's shareholders, who bear the burden of a damage award, are as innocent as the plaintiffs suggests another method of measuring damagesnamely, apportioning the losses among the plaintiffs and the shareholders on the basis of their relative stock ownership. ${ }^{47}$ Each plaintiff and each shareholder would bear the same loss per share of stock. This approach would view compensation of the plaintiffs on a par with protecting the investments of the corporation's innocent shareholders. The damage figure assessed against the corporation would generally be less than the total losses suffered as a result of the misrepresentation, ${ }^{48}$ but would assure the plaintiffs some measure of compensation and would provide a substantial deterrent to negligence in the preparation of releases. ${ }^{49}$

${ }^{46}$ The Tenth Circuit in Mitchell approved the recovery of interest from the time of sale until the date of the trial court's judgment. $446 \mathrm{~F} .2 \mathrm{~d}$ at 106.

${ }^{47}$ For purposes of the immediate discussion, plaintiffs and shareholders are considered to be mutually exclusive groups. The case which involves plaintiff shareholders will be discussed shortly.

${ }^{48}$ As will soon be shown, the damage award will be equal to the total losses in the case in which all plaintiffs are shareholders.

${ }^{49} \mathrm{Clearly}$ the most effective deterrent would be provided by the assessment of 1 direct fine against the individuals responsible for the negligent misrepresentation. The direct deterrent could be a fixed fine per misrepresentation, or could be a percentage of each individual's income. A direct deterrent could easily be combined with the adjusted pro rata loss method or the percentage-of-corporate earnings method of determining the corporation's liability. Complete treatment of the advisability and feasibility of such a direct deterrent is beyond the scope of this Comment, but several observations are in order.

The direct deterrent loses most of its effectiveness if the corporation indemnifies the responsible individuals for their loss. A court determined to assess an effective direct deterrent must be prepared to set aside by-laws and statutes that permit indemnification. The New York and Delaware statutes permit indemnification of officers against expenses, judgments, fines, and amounts paid in settlement in connection with a suit, if the officer acted in good faith and in a manner which he reasonably believed to be in the best interests of the corporation. N.Y. BuS. CORP. LAW $\S 723$ (McKinney 1963); DEL. CODE ANN. tit. 8, $\S 145$ (Supp. 1970). These statutes appear to permit indemnification in most cases of negligent misrepresentation. (For a criticism of the permissiveness of the Delaware statute in this respect, see Bishop, Sitting Ducks and Decoy Ducks: New Trends in Indemnification of Corporate Directors and Officers, 77 YALE L.J. 1078, 1081-85 (1968).) In some cases courts have ignored or circumvented statutory indemnification provisions when they found breaches of duty. See, e.g., SEC v. Continental Growth Fund, CCH FED. 
The mechanics of determining the damage figure which would produce a proportional allocation of losses among the shareholders and the plaintiffs would differ in the several possible situations in which suits could arise: (1) the plaintiffs are sellers; (2) the plaintiffs are buyers, all of whom have since sold their stock; (3) the plaintiffs are buyers, all of whom hold their stock at the time of the judgment; and (4) the plaintiffs are buyers, some of whom hold their stock at the time of judgment and some of whom have sold their stock.

In the first two cases, the plaintiffs and the shareholders are two mutually exclusive groups, and it is a simple matter to calculate each group's proportional share of the losses. If, for example, the plaintiffs lost $\$ 5$ million through the sale of 500,000 shares of stock, and there were at the time of judgment 2 million outstanding shares, the $\$ 5$ million loss would be apportioned among the total number of shares represented by the plaintiffs $(500,000)$ and the current shareholders (2 million) at $\$ 5$ million $/ 2.5$ million shares, or $\$ 2$ per share. The corporation would pay damages of $\$ 2 \times 2$ million, or $\$ 4$ million, and the plaintiffs would bear $\$ 2 \times 500,000$, or $\$ 1$ million of the loss. Stated algebraically, if $L$ is the total loss suffered in reliance upon the misrepresentation, $\mathrm{S}_{a}$ is the number of shares once held by the plaintiffs, and $S$ is the number of outstanding shares, the formula for arriving at the proper damage award (D) would be:

$$
\mathrm{D}=\mathrm{L}\left(\frac{\mathrm{S}}{\mathrm{S}+\mathrm{S}_{a}}\right)
$$

In the third case of plaintiff-buyers who hold all of their stock at the time of the judgment, the plaintiffs and the shareholders are not two mutually exclusive groups. If the adjusted pro rata loss theory sought merely a proportional allocation between two potentially overlapping groups (plaintiffs and shareholders) and were not concerned about the overlap, then the damages to be assessed against the corporation would be calculated according to the formula derived for the first two cases. But the adjusted pro rata loss theory seeks to allocate losses proportionately among all the individuals who are now shareholders or plaintiffs. The two groups between which the theory seeks to divide the losses on a pro rata basis are the mutually

SEC. L. REP. I 91,437 (S.D.N.Y. 1964); Teren v. Howard, 322 F.2d 949 (9th Cir. 1963); Essential Enterprises Corp. v. Dorsey Corp., 40 Del. Ch. 343, 182 A.2d 647 (Ch. 1962). It is submitted that the overriding federal policy of deterring violations of rule $10 \mathrm{~b}-5$ offers justification for refusing indemnification, regardless of the provisions of state law and corporate by-laws. See Note, 76 HARV. L. REV. 1403 (1963). For a more complete discussion of corporate indemnification, see G. WASHINGTON \&J. BISHOP, INDEMNIFYING THE CORPORATE ExECUTIVE (1963); Bishop, Sitting Ducks and Decoy Ducks: New Trends in the Indemnification of Corporate Directors and Officers, 77 YALE L.J. 1078 (1968); Sebring, Recent Legislative Changes in the Law of Indemnification of Directors, Officers and Others, 23 Bus.LAw.95 (1967); Note, 76 HARV. L. REv. 1403 (1963). 
exclusive groups of plaintiffs (whether shareholders or not) and nonplaintiff shareholders. It is essential, therefore, that the calculation of the damage award in the third case take account of the fact that the plaintiffs, as shareholders, would bear a portion of the burden of their own damage award. Once it is acknowledged that the plaintiff shareholder's net loss includes both his uncompensated loss and his portion of the corporation's damage burden, it becomes clear that in cases in which all plaintiffs retain all their shares, a pro rata allocation can only be attained by charging the corporation with liability for the full measure of the losses sustained as a result of the misrepresentation. Both the plaintiff shareholders and the nonplaintiff shareholders would suffer their pro rata loss by virtue of the decrease in value of each share of their stock.

Many cases involving plaintiff-buyers will fall into the fourth category of cases, in which some of the plaintiffs hold their stock at the time of the judgment and some have sold their stock by that time. ${ }^{50}$ It is possible to derive for these cases a somewhat complicated damage formula that will allocate to the plaintiffs and the nonplaintiff shareholders their pro rata share of the total loss. ${ }^{51}$

Liability insurance also poses a threat to the effectiveness of a direct deterrent assessed against the responsible individuals. Corporate employees can purchase policies covering negligence, and their corporate employers can purchase the policies for them. It should be impermissible to defeat the federal policy of deterring rule $10 \mathrm{~b}-5$ violation by purchasing such insurance. For a more complete discussion of corporate liability insurance, see Bishop, New Cure for an Old Ailment: Insurance Against Directors' and Officers' Liability, 22 Bus. LAw. 92 (1966); Note, Liability Insurance for Corporate Executives, 80 Harv. L. Rev. 648 (1967); Note, Public Policy and Directors' Liability Insurance, 67 COLUM. L. REV. 716 (1967).

${ }^{50} \mathrm{~A}$ plaintiff who sold some shares and retained others would fall within both classes. Under the formula developed in note 51 infra, his shares would be allocated between the two relevant classifications.

${ }^{1}$ Where $a$ is the group of plaintiffs who remain shareholders, $b$ is the group of plaintiffs who sold their shares, and $c$ is the group of nonplaintiff shareholders, NL $\mathrm{N}_{t}$ is the net loss of group $i$, and $S_{i}$ is the number of shares represented by group $i$, the damage award should produce a situation in which each group bears the same per-share loss, i.e.

$$
\frac{\mathrm{NL}_{a}}{\mathrm{~S}_{a}}=\frac{\mathrm{NL}_{b}}{\mathrm{~S}_{b}}=\frac{\mathrm{NL}_{c}}{\mathrm{~S}_{c}}
$$

Where $L_{i}$ is the initial loss suffered by group $i$, and $P_{i}$ is the amount which group $i$ recovers from the corporation, the net loss of each group is as follows:

$$
\mathrm{NL}_{a}=\mathrm{L}_{a}-\mathrm{P}_{a}+\left(\frac{\mathrm{S}_{a}}{\mathrm{~S}_{a}+\mathrm{S}_{c}}\right)\left(\mathrm{P}_{a}+\mathrm{P}_{b}\right)
$$

The final term, which is a's contribution, as corporate shareholders, to the corporation's damage payment, is eliminated in considering the net loss of those plaintiffs who sold their shares:

$$
\mathrm{NL}_{b}=\mathrm{L}_{b}-\mathrm{P}_{b}
$$

And finally:

$$
\mathrm{NL}_{c}=\left(\frac{\mathrm{S}_{c}}{\mathrm{~S}_{a}+\mathrm{S}_{c}}\right)\left(\mathrm{P}_{a}+\mathrm{P}_{b}\right)
$$


In each of the four situations discussed, adjustments can be made in the formulas to increase the relative share of the loss sustained by the corporation. Any one of three considerations could lead a court to make such adjustments: the court may feel that the shareholders of the corporation are in some sense less innocent than the plaintiffs, and therefore ought to bear a proportionally larger share of the loss; $;^{52}$ the court may want to

The only unknown terms in these equations are $\mathrm{P}_{a}$ and $\mathrm{P}_{b}$. The sum of these two terms is the proper damage award. Substituting these values for net loss into the first set of equations (1), and solving those equations simultaneously, we arrive at the following values for $P_{a}$ and $P_{b}$ :

$$
\begin{aligned}
& \mathrm{P}_{a^{\prime}}=\mathrm{L}_{a}, \text { and } \\
& \mathrm{P}_{b}=\frac{\mathrm{S}_{a} \mathrm{~L}_{b}-\mathrm{S}_{c} \mathrm{~L}_{b}-\mathrm{S}_{b} \mathrm{~L}_{a}}{\mathrm{~S}_{a}+\mathrm{S}_{b}+\mathrm{S}_{c}}
\end{aligned}
$$

Once again the plaintiff shareholders receive an award equal to their damages, although their net benefit is reduced by the corporation's contribution to the plaintiff nonshareholders, who in turn, being disassociated from the corporation, must pay their share of the award to the plaintiff shareholders out of the cash award. The corporation's damage payment (D) should be:

$$
\mathrm{D}=\mathrm{L}_{a}+\frac{\mathrm{S}_{a} \mathrm{~L}_{b}+\mathrm{S}_{c} \mathrm{~L}_{b}-\mathrm{S}_{b} \mathrm{~L}_{a}}{\mathrm{~S}_{a}+\mathrm{S}_{b}+\mathrm{S}_{c}}
$$

Using this formula, if the plaintiffs in group $a$ held 1 share and suffered a loss of $\$ 20$, the plaintiffs in group $b$ suffered a $\$ 30$ loss in selling 2 shares, and group $c$ nonplaintiff shareholders held 5 shares, the corporation would pay $\$ 37.50$ in damages, of which \$17.50 would be paid to the plaintiffs who sold and \$20 would be paid to the plaintiff shareholders. Each group would thereby suffer a net loss per share of $\$ 6.25$.

${ }^{52}$ In the case in which all plaintiffs retain their stock, this adjustment would produce a damage award larger than the amount of total losses. A court would understandably be unwilling to make such an adjustment. In the other cases discussed, the adjustment could increase the damage award without pushing it over the total amount of losses.

The adjustment can be demonstrated in the most complicated case-the case involving plaintiff buyers, some of whom retain their stock and some of whom have sold their stock. The adjustment would be made by redefining the desired result expressed in the first set of equations in note 51 supra to indicate that the nonplaintiff shareholders should bear more than their proportionate share of the loss. A factor of less than $\left(\frac{1}{x}\right)$ would be inserted before the final term of that equation, which stands for group $c$ 's net loss per share, as follows:

$$
\frac{N L_{a}}{S_{a}}=\frac{N_{L_{b}}}{\mathrm{~S}_{b}}=\left(\frac{1}{x}\right)\left(\frac{N L_{c}}{\mathrm{~S}_{c}}\right)
$$

The derivation of the damage award would then proceed as in note 51 supra.

Although group $a$ in the above equation (the group of plaintiff shareholders) obviously contains shareholders, the factor $\frac{1}{x}$ should not be added to the first term of the equation, which stands for the plaintiff shareholders' per-share loss. Shareholders who held their shares at the time of the misrepresentation might be thought to be responsible for the misrepresentation in the sense that they, theoretically at least, were responsible for choosing the negligent officers. And nonplaintiff shareholders who purchased shares after the misrepresentation would be responsible in the same way that they are responsible for all contingent liabilities of the corporation. But it would be unreasonable to suggest that a purchaser of shares should be held to assume any portion of the corporation's responsibility for negligently inducing him to purchase the corporation's stock. Therefore the plaintiff shareholders are in a different position from the nonplaintiff shareholders. 
account for the likelihood that the corporation's damage payments would produce less than a dollar-for-dollar decline in the value of its stock; ${ }^{53}$ or the court may want to account for the fact that when the damage award is deducted from the corporation's taxable income, ${ }^{54}$ the corporation's net loss, and the shareholders' net loss, are reduced by virtue of the tax savings. ${ }^{55}$

Apportionment of losses under the adjusted pro rata loss theory would adequately serve the competing policies that must be considered in determining liability for negligent misrepresentations. It would supply a significant deterrent and would provide a substantial measure of compensation. At the same time

While this note has demonstrated how a court could take into account its belief that the shareholders are less innocent than the plaintiffs, it is submitted that it is a fiction to speak of fault at all in the context of shareholders and plaintiffs. Allocation of losses should be made without regard to notions of the relative degree of fault as between shareholders and plaintiffs.

${ }^{53}$ To make this adjustment, the court would be required to derive a fraction that stands for the decrease in the aggregate value of all outstanding stock which would result from each dollar of damages. In the derivation of a damage formula in note 51 supra, the expression for $\mathrm{NL}_{c}$ in the fourth equation in note 51 supra and the comparable expression in the second equation for $a^{\prime}$ s contribution to the damage payment would be multiplied by that fraction.

${ }^{54}$ Expenses incurred by a corporation in issuing stock are treated as nondeductible capital outlays. General Bancshares Corp. v. Commissioner, 326 F.2d 712 (8th Cir. 1964) (stock dividend expense); Simmons Co. v. Commissioner, 33 F.2d 75 (Ist Cir. 1929); Pacific Coast Biscuit Co., 32 B.T.A. 39 (1935); Commercial Inv. Trust Corp., 28 B.T.A. 143 (1933), aff'd per curiam, 74 F.2d 1015 (2d Cir. 1935); Rev. Rul. 67-125, 1967-1 Cum. Bull. 31; B. BitTKer \& J. Eustice, Federal InCOMe Taxation of CORPORATIONS AND SHAREHOLDERS, $§ 5.04$ (4), at 5-14 (3d ed. 1971).

But in the cases with which we are dealing, the corporation which incurs liability for misrepresentation is not engaged in the issuance of stock or in any other activity which would cause the damage payment to be categorized as a capital outlay. It might be suggested that in the Texas Gulf Sulphurcase, the damage award was an expense incurred in the purchase of land in that TGS would have had to pay a higher price for the land if it had chosen to issue an accurate report. But that suggestion assumes that the misrepresentation was a deliberate one. If it was deliberate, then a fully compensatory award would be granted, and there would be no need to consider tax consequences in arriving at a compromise measure of damages which is fair to all parties.

Damage payments for negligently prepared releases would not fall within the exceptions under the public policy doctrine to the rule of deductions for all "ordinary and necessary" business expenses. INT. REv. CODE OF 1954, $\$ 162$ (a). Sections 162 (c),(f), and $(\mathrm{g})$, added by the Tax Reform Act of 1969 , provide that no deductions shall be allowed for certain illegal payments, fines, and antitrust damage payments. But damage payments in $10 \mathrm{~b}-5$ cases do not fall within any of these specific exceptions, and the Senate Report stated that the new statutory coverage "is intended to be all inclusive" and that "public policy, in other circumstances, generally is not sufficiently clearly defined to justify the disallowance of the deductions." S. REP. NO. 91-552,91 st Cong., 1st Sess. 274 (1969). For a discussion of the provisions added in 1969 and the applicability of the public policy doctrine in situations not covered by those provisions, see Taggart, Fines, Penalties, Bribes, and Damage Payments and Recoveries, 25 TAX L. REV. 611 (1970).

55 In the derivation of a damage formula in note 51 supra, the expression for $\mathrm{NL}_{c}$ in the fourth equation and the comparable expression in the fourth equation for $d$ s contribution to the damage payment would be multiplied by a fraction equal to 1 minus the corporation's net tax rate. 
it would allay to some extent fears that negligent mistakes would expose corporations to destructive liability and innocent shareholders to undeserved losses. The adjusted pro rata loss approach to measuring damages could be combined with a percentage-of-earnings schedule of payment ${ }^{56}$ to reduce further the debilitating effects of large damage awards.

The adjusted pro rata loss theory also contains a special safeguard against crushing liability in actions brought by large plaintiff classes. Under the theory, the corporation's proportionate share of the losses is inversely related to the relative number of plaintiffs (the number of plaintiffs in relation to the number of shareholders). And to the extent that the relative amount of the losses (the amount of the losses in relation to the corporation's net worth) is directly related to the relative number of plaintiffs, the corporation's proportionate share of the losses is also inversely related to the relative amount of the losses. In cases in which a relatively large number of plaintiffs suffer huge losses-cases which pose the greatest threat to the corporation and its shareholders under a system of all-ornothing liability - the corporation would bear a relatively small share of the losses. ${ }^{57}$ Only in cases in which a relatively small number of plaintiffs suffer losses would the corporation bear a relatively large share of those losses. The adjusted pro rata loss approach would offer little protection to the corporation in such cases if plaintiffs were to suffer aggregate losses which were large in relation to the corporation's net worth.

The risk remains under the adjusted pro rata loss approach that a significant portion of the damage award will be passed on to consumers in the form of price increases. But this risk is inherent in any situation involving significant business losses, and is probably beyond the control of a court fashioning damage remedies.

\section{ADOPTION OF A BALANCING THEORY OF DAMAGES}

\section{A. Fudicial Power to Apportion Losses}

The suggestion that courts should find liability under rule $10 \mathrm{~b}-5$ for negligent misrepresentation in corporate releases,

${ }^{56}$ See text accompanying notes 45-46 supra.

${ }^{57}$ Of course, the accuracy of this observation is decreased to the extent that plaintiffs are also shareholders. Thus, for example, in the case in which the plaintiffs were buyers, all of whom retained their stock, the corporation would bear the entire loss under the adjusted pro rata loss approach. But this qualification of the special safeguard is of limited consequence, for to the extent that the safeguard is not operative-that is, to the extent that the plaintiffs are shareholders-there is less need for the safeguard-that is, there is less need to protect the shareholders at the expense of the plaintiffs. 
limiting damages to an amount which is fair to all parties, has received support from previous commentators. ${ }^{58} \mathrm{It}$ does conflict, however, with the traditional tort principle that the parties who are legally responsible for someone else's loss should be liable for the full measure of that loss. But in fashioning remedies "to make effective the congressional purpose,"59 courts should not feel bound by the principles of tort law. ${ }^{60}$ Liability for the full measure of losses may be an inappropriate sanction for negligently prepared releases, as to which the very question of liability involves the delicate balancing of competing policy considerations. It is the assertion of this Comment that the balance should be struck in favor of liability, but the equilibrium point may fall short of liability for all losses suffered.

The concept of limiting recoverable damages is hardly novel. The Warsaw Convention imposes limitations on a passenger's damages for personal injury or death caused by an aviation accident. $^{61}$ Some states limit damages under their wrongful death statutes, ${ }^{62}$ and the Uniform Commercial Code explicitly approves contractual provisions placing reasonable limitations on damages ${ }^{63}$ Similary, in criminal cases mitigating circumstances do not bar conviction, but are reflected in the sentence eventually imposed.

But despite the Supreme Court's invitation to judicial innovation in F.I. Case Co. v. Borak, ${ }^{64}$ there is little, if any, direct

582 A. Bromberg, Securities LAW: Fraud $\$ 8.4$ (508), at 204.113-15 (1971); Sandler \& Conwill, Texas Gulf Sulphur: Reform in the Securities Marketplace, 30 OHIOST. L.J. 225, $273-75$ (1969); Feuerstein, The Corporation's Obligations of Disclosure under the Federal Securities Laws When It Is Not Trading in Its Stock, 15 N.Y.L.F 385, 401-03 (1969).

For the view that something more than negligence should be shown in order for a corporation to be liable for any damages caused by a misleading release, see E. GADSBY, Il-a Business ORganizations: SecuRIties Regulation $§ 5.03$ [2] [b] [i] (1973); W. Painter, Federal Regulation of Insider Trading 246 (1968); Fleisher, "Federal Corporation Law": An Assessment, 78 HARv. L. Rev. 1146, 1157 (1965); Jennings, Insider Trading in Corporate Securities: $A$ Survey of Hazards and Disclosure Obligations Under Rule 70b-5, 62 Nw. U.L. REv. 809, 826, 828 n.88 (1968); Ruder, Texas Gulf Sulphur-

The Second Round: Privity and State of Mind in Rule 10b-5 Purchase and Sale Cases, 63 Nw. U.L. REv. 423, 444-45 n. 107 (1968); Recent Case, 82 HARV. L. REv. 938, 947-50 (1969); Note, Civil Liability Under Section 10B and Rule 10B-5: A Suggestion for Replacing the Doctrine of Privity, 74 YALE L.J. 658, 688 (1965). For a very interesting and novel analysis of the problem of rule $10 \mathrm{~b}-5$ liability and the conflicting standards of negligence and scienter, see Mann, Rule 10b-5: Evolution of a Continuum of Conduct to Replace the Catch Phrases of Negligence and Scienter, 45 N.Y.U.L. REv. 1206 (1970).

${ }^{59}$ J.I. Case Co. v. Borak, 377 U.S. 426, 433 (1964).

${ }^{60}$ Speech by Robert H. Mundheim to the Association of the Bar of the City of New York, Damages Under Rule 10b-5 (How High is Up?), May 19, 1969, at 6.

oi 49 Stat. 3019 , T.S. No. 876 (1934).

${ }^{62}$ See, e.g., Kan. STAT. ANN. $\$ 60-1903$ (Supp. 1972); Mass. GEN. Laws ANN. ch. 229 (Supp. 1972); Mo. Rev. STAT. \$ 537.090; N.H. Rev. StaT. ANN. ch. 556:13 (Supp. 1970); VA. CODE ANN. \$ 8-636 (Supp. 1973); W. VA. CODE ANN. § 55-7-6 (Supp. 1972); WIS. STAT. $\$ 895.04(4)$ (Supp. 1973).

${ }^{63}$ UNIFORM COMMERCIAL CODE $\$ 2-718,719$.

${ }^{64} 377$ U.S. 426 (1964). Seenote 5 supra. 
support for judicially imposed limitations on damages. On rare occasions, courts have apportioned damages in cases in which both parties were at fault. For example, the admiralty practice of dividing losses equally in collision cases involving contributory fault is a judge-made rule. ${ }^{65}$ Georgia's rule of comparative negligence, apportioning damages between the plaintiff and defendant when both are negligent, was also developed judicially before its codification. ${ }^{6}$ The experience of Georgia, however, is the exception rather than the rule. Despite strong support among commentators for the apportionment of tort losses through a scheme of comparative negligence, ${ }^{67}$ most courts have felt that if the longstanding rule of contributory negligence is to be discarded, legislatures rather than courts should be responsible. ${ }^{68}$

Judicial reluctance to abandon the judge-made rule of contributory negligence in favor of a rule of comparative negligence is due primarily to concern over the far-reaching effects of the change and the difficulty of formulating a comprehensive plan for apportioning losses in cases involving varied relative degrees of fault among plaintiffs and defendants. Commentators have offered arguments which drain such concerns of much of their force ${ }^{69}$ But granting the cogency of these judicial concerns in the case of comparative negligence, they are of far less significance when applied to the differing situation of liability under rule $10 \mathrm{~b}-5$ for negligently prepared releases. The effects of apportioning losses in the corporate release cases would not be as far-reaching as those of judicial adoption of a rule of comparative negligence. Comparative negligence would apply to all tort cases, and would arguably decrease the incentive to act with due care. Apportionment of losses caused by a negligently prepared press release would be limited to specific situations arising under a specific statute. In view of existing law in the Second Circuit, offering corporations

${ }^{65}$ The Schooner Catharine v. Dickinson, 58 U.S. (17 How.) 170 (1854); R. KEETON, VENTURING TODO JUSTICE 46-47 (1969).

${ }^{66} \mathrm{R}$. KEETON, supranote 65 , at $46-47$.

${ }^{67}$ See, e.g., 2 F. HARPER \& F. JAMES, TORTS $\S \S 22.1-.3$, at $1193-209 ; \S 22.11$, at $1236-41$ (1956); W. ProssEr, TORTS 433-39 (4th ed. 1971); Maloney, From Contributory to Comparative Negligence: $A$ Needed Law Reform, 11 U. Fla. L. ReV. 135 (1958); Mole \& Wilson, A Study of Comparative Negligence (2 parts), 17 CoRNELl L.Q. 333, 604 (1932); Peck, Comparative Negligence and Automobile Liability Insurance, 58 MICH. L. REv. 689 (1960); Philbrick, Loss Apportionment in Negligence Cases (2 parts), 99 U. PA. L. REv. 572, 766 (1951).

${ }^{68}$ See, e.g., Maki v. Frelk, 40 Ill. 2d 193, 239 N.E.2d 445 (1968), rev'g 85 Ill. App. 2d 439,229 N.E.2d 284 (1967).

${ }^{69}$ See, e.g., id. at 196-97, 239 N.E.2d at 447; R. KEETON, supra note 60 , at 46 ; James, Kalven, Keeton, Leflar, Malone \& Wade, Comments on Maki v. Frelk-Comparative v. Contributory Negligence: Should the Court or Legislature Decide?, 21 VAND. L. REV. 889, 918, 920-21 (1968) (Comment of R. Leflar). 
complete escape from liability for negligence, ${ }^{70}$ apportionment would increase the incentive to act with due care. The difficulties inherent in the formulation of a comprehensive comparative negligence plan to deal with variations in the relative fault of plaintiffs and defendants are not present in the apportionment of losses caused by a negligently prepared release, involving innocent plaintiffs and shareholders responsible only because of their relationship to the culpable individuals.

Thus, judicial reluctance to abandon the rule of contributory negligence should not preclude judicial adoption of a scheme apportioning losses caused by a negligently prepared press release. While there is little direct support for judicial apportionment of losses, there are no bars to such apportionment. If cogent arguments can be advanced in support of limitation of damages through the apportionment of losses, courts should respond to those arguments by adopting such a scheme.

\section{B. Avoiding Arbitrariness and Setting Standards}

Any theory of damages other than that which is strictly compensatory must necessarily involve the exercise of discretion and judgments that are ultimately arbitrary. The adjusted pro rata loss theory minimizes the degree of arbitrariness, however. Of course, courts could depart from an equal pro rata sharing of the loss in favor of imposing a larger proportion on the nonplaintiff shareholders, reintroducing a significant element of discretion.

In choosing among damage awards which do not compensate fully, the courts would do well to look to the standards which have guided them when their awards more than compensate - that is, when they award punitive damages. There are no rigid formulas or fixed standards for determining the proper measure of punitive damages. ${ }^{71}$ Juries are given wide discretion to tailor punitive damage awards to fit the particular circumstances. ${ }^{72}$ The most useful guideline provided by the courts is that the punitive damages should bear some reasonable relation to the harm done and the flagrancy of the conduct involved, although the defendant's circumstances may be

${ }^{70}$ See note 28 supra \& accompanying text.

${ }^{71}$ See, e.g. I.H.P. Corp. v. 210 Central Park South Corp., 16 App. Div. 2d 461, 228 N.Y.S.2d 883 (1962), affd, 12 N.Y.2d 329, 189 N.E.2d 812, 239 N.Y.S.2d 547, (1963); Goines v. Pennsylvania R.R., 208 Misc. 103, 143 N.Y.S.2d 576 (1955), rev'd on other grounds, 3 App. Div. 2d 307, 160 N.Y.S.2d 39 (1957); DeMarasse v. Wolf, 140 N.Y.S.2d 235 (1955); 9 ENCYCLOPEDIA OF N.Y. LAW DAMAGES $\$ 67$, at 58 (1965).

${ }^{72}$ See, e.g., DeMarasse v. Wolf, 140 N.Y.S.2d 235 (1955); 9 ENCYClOPEDIA OF N.Y. LAW DAMAGES, $\$ 67$, at 58 (1958); McCoRMICK, LAW OF DAMAGES $§ 85$, at 296 (1935). 
considered as well. ${ }^{73}$ Such generalizations are of limited utility, but it is unlikely that any more specific guidelines can be devised to cover the diverse circumstances under which the courts may be called upon to award damages for negligently prepared releases.

The lack of specific, easily applied standards may be a source of discomfort to the courts, but it should not restrict them to an all-or-nothing approach to liability. Once the conflicting policy considerations are acknowledged, an all-or-nothing approach becomes more arbitrary than an approach which reflects a resolution of those conflicts in the assessment of damages.

\section{THE NEED FOR LEGISLATIVE ACTION}

Courts should feel free to balance conflicting policies in computing damages, finding liability for negligently prepared releases and developing a compromise measure of damages reflecting those considerations. But the scarcity of precedent for judicial apportionment of loss will most probably deter courts from adopting such a theory of damages under rule 10b-5 for misleading releases. Thus, legislative action establishing a compromise measure of damages may be desirable. If apportionment of loss is the preferable approach-and it certainly is preferable to having those who innocently relied on the misrepresentation bear their entire loss-legislative action offers the advantage of ensuring universal application and relatively speedy adoption of an apportionment theory.

Congressional authorization of apportionment of damages should be restricted to a limited class of cases involving negligent conduct and losses which, if imposed on the corporation, would have a destructive impact. In cases involving fraud, the present rule holding the corporation liable for all losses ${ }^{74}$ should not be eroded. ${ }^{75}$ When conduct is negligent but imposition of the full measure of compensation would not have a destructive impact on the corporation, the public interest is best served by a fully

${ }^{73}$ I.H.P. Corp. v. 210 Central Park South Corp., 16 App. Div. 2d 461, 228 N.Y.S.2d 883 (1962), affd, 12 N.Y.2d 329, 189 N.E.2d 812, 239 N.Y.S.2d 547, (1963); DeMarasse v. Wolf, 140 N.Y.S.2d 235 (1955): Cotton v. Cooper, 209 S.W. 135 (Tex. Com. App. 1919); Hall Oil Co. v. Barquin, 33 Wyo. 92, 237 P. 255 (1925); 9 ENCYCLOPEDIA OF N.Y. LAW DAMAGES, $\S 67$, at 58; C. MCCORMICK, LAW OF DAMAGES $\$$, at 29 (1935).

${ }^{74} \mathrm{See}$ Astor v. Texas Gulf Sulphur Co., 306 F. Supp. 1333, 1334 (S.D.N.Y. 1969).

${ }^{75}$ The theories of damages developed herein could quite easily be applied to cases involving fraudulent releases, if it were felt that due to unusual circumstances public policy demanded a mitigation of the damages assessed against the corporation issuing the release. Normally, however, in cases involving fraud the balance of interests should result in application of the full measure of damages that has traditionally been assessed whenever liability has been found-full compensation for actual losses suffered. 
compensatory damage award. Of course, although it could enact standards that would encourage and guide judicial action, Congress should not attempt to define precisely what amount of loss would have a destructive impact. This determination is better left to the courts, which can analyze such factors as the corporation's assets and earnings on a case-by-case basis.

\section{CONCLUSION}

The worst solution to the problems posed by negligently prepared releases is to excuse the issuer of the misstatement, shielding him from liability in the interests of protecting innocent shareholders and encouraging the release of information. Healthy securities markets depend upon full and accurate disclosure, and investors are injured as much by negligent misstatements as by deliberate ones. The primary concerns of courts should be to deter such misstatements and to provide compensation to those who suffered in reliance upon the misrepresentation. Concern over hurting innocent shareholders should be tempered by recognition that by taking an ownership interest in the corporation, the shareholders assume the risk that the corporate officers will make poor business decisions or incur civil liability. Courts cannot escape the reality that excusing the corporation and its shareholders means imposing the losses caused by the corporation on those who innocently relied upon the corporation's misrepresentation. The theoretical and policy justifications for imposing liability upon the corporation and its shareholders are stronger than those for imposing the losses on innocent reliant parties.

Although protection of the investing public requires that economic sanctions be imposed for all misrepresentations, willful or merely negligent, courts must also be sensitive to the destructive impact which such liability can have upon corporations and their shareholders. Limited liability for negligent misrepresentations may be the only approach which adequately safeguards the interests of all parties-the corporation and its shareholders, the investors who suffered in reliance upon the misrepresentation, the investing public at large, and the broader consuming public which benefits from the continuation of the corporation's activity and, indirectly, from a healthy investing atmosphere. Statutory approval of the apportionment of losses in instances of negligently prepared press releases would insure the immediate universal application of an apportionment theory. However, in the absence of congressional action, the courts themselves should move to impose liability but limit recoverable damages. 